\title{
Phytoplankton community in relation to physico-chemical characteristics of the Talar River, Iran
}

\author{
*JAFARI, N; ALAVI, S S \\ Department of Biology, Faculty of Basic Sciences, Mazandaran University, \\ Babosar, Iran \\ *Corresponding author (e-mail: n.jafari@umz.ac.ir, Tel: +981125242161)
}

\begin{abstract}
The community structure of plankton was studied in relation to physico-chemical characteristics of the river Talar polluted by industrial effluents and domestic sewage from November 2008 to July 2009. In addition, seasonal changes in phytoplankton and zooplankton populations and species abundance were also determinate. The dominant phytoplanktonic algae determined were Oscillatoria, Anabaena, Nostoc, Spirogyra, Pediastrum, Navicula and Nitzschia. The dominant zooplanktonic organisms determined were Paramecium, Daphnia, Cypris, Keratalla and Arachinous. The present study on ecology and the surface water of this fresh water river covered a number of aspects, beginning from abiotic and biotic parameters to pollution assessment and thereby reveals a true picture of the water quality of the river.@JASEM
\end{abstract}

Studies on the structure and functioning of planktonic communities in reservoir ecosystems provide opportunities to investigate patterns of responses to cyclical variations and episodic disturbances. The understanding of plankton dynamics in reservoirs can also be useful to evaluate the resilience of this kind of ecosystem, which can present deep changes in limnological conditions in relatively short periods. This dynamic is generated by short-term variations in the water retention time, flux regime, outflow and level and by interactions with other aquatic and terrestrial ecosystems in the catchment area. The heterogeneity frequently observed in the distribution of zooplankton in reservoirs is caused by interactions between physical and biological processes.

This variability is related to water movements and to the quality and quantity of resources brought into the system by tributary rivers (Threlkeld and Choinsk, 1985; Dirnberg and Threlkeld, 1986; Marzolf, 1990; Betsil and Van Den Avyle, 1994). During periods of high flux, the structure of the plankton can be strongly influenced by differential loss of organisms as a consequence of their vertical position in the water column, swimming capacity and reproductive rates. However, the interference can also be indirect, through modifications in the physical and chemical conditions of the environment. In addition to typical longitudinal gradients generally observed in reservoirs, lateral components, such as arms and bays, can contribute significantly to the maintenance of heterogeneous patterns in the zooplankton distribution (Van Den Brink et al., 1994).

Despite of the importance of physical-biological interactions, the structure of the zooplankton in reservoirs can also be influenced by biological interactions and adaptative characteristics (Horn et al., 1987; Urabe, 1989 and 1990). According to Betsil and Van Den Avyle (1994) there is no consensus on whether the heterogeneity of the spatial distribution of the plankton of reservoirs is stable or ephemeral. They stress the relative importance of the spatial and temporal components on heterogeneity, the influence of longitudinal gradients along the main axis, and the influence of the main tributaries.

In most developing countries, point and nonpoint source pollution are major environmental problems affecting water quality. The situation is exacerbated by lack of or scarcity of treatment for domestic wastes (Dudgeon, 1992) and poor agricultural practices (Iwata et al., 2003). Microinvertebrate assemblages have been used as bioindicators of stream biological integrity (Hepp et al., 2010; Collins et al., 2008; Miltner et al., 2004; Stepenuck et al., 2002). Within this framework, the use of a multimetric approach that utilizes the index of biotic integrity (IBI) (Karr, 1981) has gained interest in biological assessment of rivers and streams in urban and suburban catchments (e.g. Collins et al., 2008; Miltner et al., 2004).

\section{MATERIALS AND METHODS}

Talar river it is located on the East of Caspian Sea, in Ghaemshahr city of Mazandaran province, Iran. Morphology of Talar river shows a combination of meander and River-Valley features. There are several meander in Talar river flow path. Talar river flows parallel with Firouzkooh-Ghaemshahr road and it arrives to Caspian beach area in Malek Kala village. Length of Talar river in Caspian beach is more than 
$25 \mathrm{Km}$. the local base level (LBL) of Talar river is $24 \mathrm{~m}$ and its bed gradient is 10/1000 (1 percent).

Talar river morphology shows an active flood plain that be confined by 2 river terraces. These terraces have different topographic contours. Maximum width of Talar river flood plane is more than 100 meters but its active flood plain width is up to 40 meters. H1 Terraces defines 20 years recurrence period area. H2 terraces have 5-7 meters height and are the topmost morphic features in Talar river. These terraces can define 100 years recurrence period flood area. Because of $\mathrm{H} 2$ terraces are away from Talar river flood flows, constructions and farms are developed in the top of them. There aren't any plants in Talar active flood plain and this trait is the most important way to recognition of flood area. Vulnerable area of Talar river lies between 1/5 Km south of Ghaemshahr (Talar village) and $300 \mathrm{~m}$ north of Talar park. Talar river approximately overflows each year. Maximum volume of Talar is end of winter and first of spring. Terraces walls in the most areas makes from Cohesive brown silts (loess) and take place of landslide in these walls are probably. The study was conducted during the period from November 2008 to July 2009. A composite sample measuring 2 liters was collected for the analysis of physico-chemical characteristics and a liter of the sample was collected separately for studying planktonic composition. The physico-chemical parameters were analyzed as per the standard methods of APHA (1989) and Saxena
(1990); Trivedy and Gole (1986). The planktonic sample later left in sediment column and planktons were concentrated as per Welch (1952) technique. Qualitative identification of phytoplanktons and zooplanktons were made with the help of monograph and research publications of Deshikachary (1959); Gandhi (1962); Welch (1952) and Prescott (1951 and 1954). Physico-chemical characteristics, phytoplankton and zooplankton composition of Talar river presented in Tables 1, 2 and 3 respectively.

\section{RESULTS AND DISCUSSION}

Physico-chemical Properties of the River: The study of Talar river was undertaken from November 2008 to July 2009 and the water quality studies consisted solely of the recording of selected physico-chemical parameters and their interpretation (Table 1). The river was recorded having temperature highest in July i.e $29.7^{\circ} \mathrm{C}$ and lowest in January i.e. $10.10^{\circ} \mathrm{C}, \mathrm{pH}$ ranging from 7.18 to 8.12 , dissolved oxygen (DO) ranging from $3.10 \mathrm{ppm}$ (July) to $5.60 \mathrm{ppm}$ (November) and conductivity was higher during summer. Observation of total alkalinity showed a definite trend in its seasonal fluctuation, which varies from $52.36 \mathrm{mg} / \mathrm{L}$ to $98.12 \mathrm{mg} / \mathrm{L}$. The phosphate content of the water body was maximum during May $(0.88 \mathrm{mg} / \mathrm{L}$ and lowest during November $(0.09 \mathrm{mg} / \mathrm{L})$ .The maximum nitrogen content was recorded during summer from $1.05 \mu \mathrm{g} / \mathrm{L}$ to $2.34 \mu \mathrm{g} / \mathrm{L}$.

Table 1: Seasonal fluctuations in physico-chemical parameters of water in Talar river during the period November 2008 to July 2009

\begin{tabular}{|c|c|c|c|c|c|c|c|c|}
\hline $\begin{array}{l}\text { Month } \\
\text { of } \\
\text { Experi } \\
\text { ment }\end{array}$ & Temp. & $\mathrm{pH}$ & $\begin{array}{l}\text { DO } \\
(\mathrm{ppm})\end{array}$ & $\begin{array}{l}\mathrm{EC} \\
(\mu S)\end{array}$ & $\begin{array}{l}\text { TA } \\
(\mathrm{mg} / \mathrm{L})\end{array}$ & $\begin{array}{l}\mathrm{Cl} \\
(\mathrm{mg} / \mathrm{L})\end{array}$ & $\begin{array}{l}\mathrm{PO}_{4}^{3-} \\
(\mathrm{mg} / \mathrm{L})\end{array}$ & 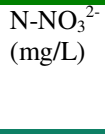 \\
\hline $\begin{array}{l}\text { Nove } \\
\text { mber }\end{array}$ & 11.20 & 8.10 & 5.60 & 17.00 & 87.31 & 40.36 & 0.09 & 1.05 \\
\hline $\begin{array}{l}\text { Decem } \\
\text { ber }\end{array}$ & 10.40 & 8.12 & 5.23 & 15.00 & 98.12 & 51.47 & 0.08 & 1.15 \\
\hline $\begin{array}{l}\text { Januar } \\
\text { y }\end{array}$ & 10.10 & 7.82 & 5.12 & 21.00 & 70.14 & 49.81 & 0.12 & 1.89 \\
\hline $\begin{array}{l}\text { Februa } \\
\text { ry }\end{array}$ & 12.60 & 7.94 & 4.80 & 32.00 & 60.69 & 62.31 & 0.41 & 1.75 \\
\hline March & 15.30 & 7.54 & 4.65 & 81.00 & 85.24 & 66.16 & 0.35 & 2.05 \\
\hline April & 19.80 & 7.32 & 4.78 & 88.00 & 55.36 & 82.52 & 0.67 & 2.11 \\
\hline May & 23.70 & 7.20 & 3.88 & 45.00 & 62.47 & 81.25 & 0.88 & 1.99 \\
\hline June & 28.60 & 7.26 & 3.95 & 28.00 & 66.25 & 92.20 & 0.95 & 2.34 \\
\hline July & 29.70 & 7.18 & 3.10 & 32.00 & 52.36 & 77.45 & 0.87 & 1.83 \\
\hline
\end{tabular}

Biological Characteristics: Observation on biological characteristics of river of Talar has been presented in Tables 2 and 3. 
Population Dynamics of Phytoplanktons: The ranges of numerical fluctuation of various planktonic groups are very important in the present study. Bimodal nature of phytoplankton was found during winter (Dec-Feb). The phytoplankton population gradually increased from March onwards maintaining more or less similar trend up to April. However, they finally exhibited a drop in population density during November to January.

Mainly five groups of algae were identified. They are (i) Chlorophyceae, (ii) Cyanophyceae (iii) Bacillariophyceae (iv) Chrysophyceae and (v) Euglenophyceae. During the period of observation a peak was found in March (486 unit/L), which gradually decreased till December (Table 4). Chlorophyceae gradually increased from February (289 unit/L) till peak was reached in March (486 unit/l). Spirogyra and Pediastrum were the prominent species among Chlorophyceae in this river. Cyanophyceae was animated species and the peak in its population occurred during May (399 unit/L). The minimum was recorded in April (155 unit /L). There was no remarkable difference in the Cyanophyta population among the observed station. The maximum Bacillariophyceae species was recorded during April (244 unit/L) and minimum during December (124 unit/L). They exhibited intrastational variation. The maximum population of Chrysophceace was observed during February (105 unit/L) and minimum during June (35 unit/L). Diatom formed the dominant Chrysophyta group which was the prominent specie observed in the river. Euglenophyceae was represented by a solitary genus Euglena and Phacus in this river. The peak in the population occurred during summer i.e. March (112 unit/L) and minimum in winter i.e December.

Population Dynamics of Zooplankton: During the present observation period, Protozoa, Rotifer, Copepod, Cladocera, Ostracoda and Crustacen larvae represented the zooplankton. In comparison to the phytoplankton population, zooplankton population was low in this water body. The zooplanktons have a single peak in March (364 unit/L) due to more abundance of Copepoda and Crustacean larvae (Table 5). The number of zooplankton showed remarkable differences among the station of this river. The maximum number of zooplankton during summer and minimum in winter was found. The occurrence of protozoa was very rare and its percentage composition was negligible. The main species were paramecium caudatum and Aroella vulgaris that did not show any seasonal fluctuation.
Rotifera the $3^{\text {rd }}$ major group of zooplanktons and showed a clear seasonal pattern of distribution. They produced a peak during April (72 unit/L) and a fall during December (15 unit/L). Cladoceran does not show any monthly fluctuation during the observation period. Daphnia species were the main representative of this group and were present in all stations. Ostracode showed a peak during April (82 unit/L) and a fall during November (31 unit/L). Cypris was the prominent species among the Ostracode.

The addition of various kinds of pollutants and nutrients through the agency of sewage, industrial effluents, and agricultural run off etc. in to the water bodies brings about a series of changes in the physico-chemical and biological characteristics of fresh water which have been the subject of several investigations (Jafari and Foroutan, 2007; Jafari and Gunale, 2007; Jafari et al., 2006.). A number of physical and biological factors operating simultaneously in the environment must be taken into consideration to understand the fluctuation of the plankton population. It has been pointed out by Mathew (1985) and that physico-chemical factors play a significant role in regulating the various seasonal biological rhythms. The adverse physicochemical conditions decrease the plankton population whereas favorable water conditions enhance the plankton growth. In general, planktonic population of the medium shows response to seasonal parameters like temperature, dissolved oxygen, $\mathrm{pH}$ and nutrient concentration of the medium and on the other hand their life processes are affected by inflow of sewage decomposition of waste materials in the catchments area.

The population of fresh water can be detected by algal genus index. A score of 20 or more secured by the algae belonging to different genera in water sample is indicative of organic pollution. Score lying between 15 to 19 is taken as a probable indication of high organic pollution. During the present study the river consisted 33 genera of algae. However, this river may be listed and polluted by genus index study. The planktons were sensitive to pollution as indicated by their fluctuation in relation to pollution level and water quality. The present study shows that the river is eutrophic in nature which is confirmed by the three indices i.e. Cyanophyceae, Chlorophyceae population and compounds present, which may be due to domestic sewage, municipal waste and effluents of organic waste of animals and human being $\mathrm{s}$ entry into the river . 
Table 2: distribution of planktonic organisms (phytoplankton)

\begin{tabular}{|c|c|c|c|}
\hline Chlorophyceae & S1 & S2 & S3 \\
\hline Chlamydomonas pertusa Chod. & - & + & + \\
\hline Chlorella vulgaris Beijerinck & - & + & - \\
\hline Closterium acerosum (Schrank) & + & - & + \\
\hline Ehr. & & & \\
\hline Closterium didymoticum Ralfs. & - & - & + \\
\hline Coelastrum scabrum Reinsch & - & + & - \\
\hline Cosmarium ralfsii Breb. & + & + & - \\
\hline Cosmarium pachydermum Lund. & - & + & + \\
\hline Gonium pectorale Muller & - & - & + \\
\hline Mougeotia parvula Hass. & + & + & + \\
\hline Oedogonium sp. & - & + & + \\
\hline $\begin{array}{l}\text { Pediastrum boryanum (Turpin) } \\
\text { Menegh. }\end{array}$ & + & - & + \\
\hline $\begin{array}{l}\text { Pediastrum simplex (Meyen) } \\
\text { Lemm. }\end{array}$ & - & + & + \\
\hline Pediastrum duplex Meyen & - & - & + \\
\hline $\begin{array}{l}\text { Scenedesmus abundance (Kirchner) } \\
\text { Chodat. }\end{array}$ & + & - & + \\
\hline $\begin{array}{l}\text { Scenedesmus bernardii G. M. } \\
\text { Smith. }\end{array}$ & - & + & + \\
\hline Spirogyra singularis Nordstedt & + & + & + \\
\hline Spirogyra nitida Tonbridge & + & + & + \\
\hline $\begin{array}{l}\text { Zygnema pectinatum (Vauch.) Ag. } \\
\text { Cyanophyceae }\end{array}$ & + & - & - \\
\hline Anabaena osillarioides Bory & - & - & + \\
\hline Lyngbya lachneri (Zimm.) Geitler. & + & + & - \\
\hline Merismopedia punctata Meyen. & - & + & - \\
\hline $\begin{array}{l}\text { Nostoc commune Vaucher ex. } \\
\text { Brunet Flav. }\end{array}$ & - & + & - \\
\hline $\begin{array}{l}\text { Oscillatoria brevis (Kuetz.) } \\
\text { Gomont }\end{array}$ & + & - & + \\
\hline $\begin{array}{l}\text { Oscillatoria chalybea (Mertens) } \\
\text { Gom. }\end{array}$ & - & + & - \\
\hline Oscillatoria formosa Bory. & - & - & + \\
\hline Oscillatoria tenuis Ag. Ex. Gomont & + & - & + \\
\hline $\begin{array}{l}\text { Phormidium subincrstatum Fritsch } \\
\text { and Rich. }\end{array}$ & - & + & - \\
\hline $\begin{array}{l}\text { Spirulina meneghiana Zonard ex. } \\
\text { Gomont }\end{array}$ & - & + & - \\
\hline Bacillariophyceae & & & \\
\hline $\begin{array}{l}\text { Amphora ovalis Kuetz. Var. } \\
\text { gracilis (Ehr.) Cleve. }\end{array}$ & - & - & + \\
\hline Cymbella cistula (Hemp.) Grum. & + & + & - \\
\hline Fragilaria capucina Desm. & - & + & - \\
\hline Fragilaria virescens Ralfs & - & + & - \\
\hline $\begin{array}{l}\text { Gomphonema angustatum (Kuetz.) } \\
\text { Rabenh. }\end{array}$ & + & - & + \\
\hline Gomphonema truncatum Ehr. & - & + & - \\
\hline Gomphonema truncatum Ehr. & - & - & + \\
\hline Melosira italica (Ehr.) Kuetz. & + & - & + \\
\hline Navicula rhynchocephala Kuetz. & - & + & - \\
\hline $\begin{array}{l}\text { Navicula tripunctata (O. F. Muell.) } \\
\text { Bory }\end{array}$ & - & + & - \\
\hline $\begin{array}{l}\text { Navicula tripunctata (O. F. Muell.) } \\
\text { Bory }\end{array}$ & - & - & + \\
\hline Nitzschia acicularis W. Sm. & + & + & - \\
\hline Nitzschia palea (Kuetz.) W. Sm. & + & + & - \\
\hline Pinnularia brevistriata Cleve & - & + & + \\
\hline Synedra ulna (Nitzsch) Ehr. & - & - & + \\
\hline Euglenophyceae & + & + & + \\
\hline Euglena charkoweinsis Swir. & - & + & + \\
\hline Euglena rubra Hardy. & + & - & + \\
\hline Euglena viridis Ehr. & + & + & - \\
\hline Phacus candatus Hubn. & - & + & + \\
\hline Chrysophyceae & - & - & + \\
\hline Dinobriyon sertularia (Ehrenberg) & + & + & + \\
\hline Paraphysomonas vestita (Stokes) & - & + & + \\
\hline
\end{tabular}

Table 3: distribution of planktonic organisms (zooplankton)

\begin{tabular}{|c|c|c|c|}
\hline Zooplankton & S1 & S2 & S3 \\
\hline \multicolumn{4}{|l|}{ Protozoa } \\
\hline Paramecium caudatum & + & - & + \\
\hline Verticella campenella & - & + & + \\
\hline Aroella vulgaris & + & - & + \\
\hline Diffugia coronoa & - & + & - \\
\hline \multicolumn{4}{|l|}{ Rotifera } \\
\hline Arachinous calcyflorus & - & + & + \\
\hline Brachinus farficula & + & - & - \\
\hline Keratalla tropica & - & + & - \\
\hline K. procurya & + & - & + \\
\hline Polyathrsp. & - & + & + \\
\hline Rolaria vulgaris & + & - & + \\
\hline \multicolumn{4}{|l|}{ Crustacea } \\
\hline $\begin{array}{l}\text { Stropocephalus } \\
\text { dichotomus }\end{array}$ & - & + & - \\
\hline $\begin{array}{l}\text { Branchnella } \\
\text { kugenamaensis } \\
\text { Cladocera }\end{array}$ & + & + & - \\
\hline Daphnia & + & + & + \\
\hline Monia micura & - & + & - \\
\hline Bosmina sp. & + & - & + \\
\hline \multicolumn{4}{|l|}{ Ostracoda } \\
\hline Cypris sp. & + & + & + \\
\hline Contriocypris & + & - & + \\
\hline Stenocyoris malcolmsoni & - & + & + \\
\hline \multicolumn{4}{|l|}{ Copepoda } \\
\hline Heliodiaptomus viddus & - & + & + \\
\hline Rhinodiaptomus indius & + & + & - \\
\hline $\begin{array}{l}\text { Spicodiaptomus } \\
\text { chelospinus }\end{array}$ & - & - & + \\
\hline Mesocyclops hyalinus & + & + & - \\
\hline Monostylla sp. & + & - & + \\
\hline Cyclops & - & - & + \\
\hline
\end{tabular}

\section{Crustacean larvae}

Nauplius

Note: $\mathrm{S} 1=$ Upstream, S2 = Midstream and S3 = Downstream 
Table 4: Monthly fluctuations of phytoplankton in water of Talar river during the period November 2008 to July 2009

\begin{tabular}{llllllllll}
\hline $\begin{array}{l}\text { Planktonic } \\
\text { groups unit /L }\end{array}$ & Nov. & Dec. & Jan. & Feb. & March & April & May & June & July \\
\hline $\begin{array}{l}\text { Bacillariophyce } \\
\text { ae }\end{array}$ & 206 & 124 & 138 & 211 & 147 & 244 & 189 & 212 & 205 \\
$\begin{array}{l}\text { Chlorophyceae } \\
\text { Chrysophyceae }\end{array}$ & 256 & 186 & 205 & 289 & 486 & 377 & 425 & 411 & 347 \\
Cyanophyceae & 196 & 155 & 216 & 169 & 321 & 249 & 399 & 335 & 261 \\
Euglenophyceae & 89 & 67 & 99 & 106 & 112 & 98 & 88 & 114 & 84 \\
\hline $\begin{array}{c}\text { Total } \\
\text { Phytoplankton }\end{array}$ & 824 & 628 & 693 & 880 & 1135 & 1014 & 1174 & 1136 & 975 \\
\hline
\end{tabular}

Table 5: Monthly fluctuations of zooplankton in water of Talar river during the period November 2008 to July 2009

\begin{tabular}{llllllllll}
\hline $\begin{array}{l}\text { Planktonic groups } \\
\text { unit } / \mathrm{L}\end{array}$ & $\begin{array}{l}\text { No } \\
\text { v. }\end{array}$ & Dec. & Jan. & Feb. & Mar & Apri & May & June & July \\
\hline Anostraca & 5 & 8 & - & - & 12 & 10 & 15 & 8 & 15 \\
Cladocera & 25 & 18 & 20 & 48 & 56 & 36 & 41 & 26 & 32 \\
Copepoda & 47 & 35 & 66 & 71 & 63 & 87 & 54 & 48 & 84 \\
Crustacean larvae & 51 & 37 & 47 & 33 & 97 & 71 & 66 & 88 & 62 \\
Ostracoda & 31 & 48 & 58 & 49 & 60 & 82 & 45 & 56 & 66 \\
Protozoa & 15 & 10 & 14 & 20 & 23 & 19 & 25 & 17 & 28 \\
Rotifera & 25 & 15 & 38 & 42 & 65 & 72 & 58 & 61 & 56 \\
\hline Total Zooplankton & $\mathbf{1 9 9}$ & $\mathbf{1 7 1}$ & $\mathbf{2 4 3}$ & $\mathbf{2 6 3}$ & $\mathbf{3 7 6}$ & $\mathbf{3 7 7}$ & $\mathbf{3 0 4}$ & $\mathbf{3 0 4}$ & $\mathbf{3 4 3}$ \\
\hline
\end{tabular}

The results of this study suggest that in the tropical condition many factors such as temperature, inter and intra-specific competition for nutrients, seasonal variation governs the occurrence and abundance of plankton. As some of these factors become limiting factors, the plankton appears and disappears without regularity. We performed a trend analysis of indicator groups revealing a typical response of plankton communities to the changes of ecological variables down the rivers and over the seasons. Thus, intensive investigation and experimental ecology of both physico-chemical and biological factors will allow us to understand more about plankton diversity and distribution in the freshwater ecosystems and it further provides support as to why plankton species and assemblages are good indicators of environmental change.

At the present phase, it is essential to use the vast knowledge accumulated on the ecology of zooplankton communities in the Talar river for the ecosystem management aimed at improving the water quality and conservation of natural biological diversity in the ecosystems.

\section{REFERENCES}

APHA (1989). Standard methods for the examination of water and wastewater. APHA, AWWA and WPCF. $16^{\text {th }}$ ed. Amer. Publ. Progr. Spring., New York.

Betsil, RK; Van Den Avyle, MJ (1994). Spatial heterogeneity of reservoir zooplankton: a matter of timing. Hydrobiologia 277: 63-70.

Collins, CL; Mullen, MW; Stewart, PM; Webber, EC (2008). Validation of an invertebrate community index for urban streams for an Alabama coastal plains watershed. J Am Wat Resour Assoc 44(3):663-669.

Desikachary, TV (1959). Cyanophyta. ICAR, New Delhi. 
Dirnberger, JM; Threlkeld, ST (1986). Advective effects of a reservoir flood on zooplankton abundance and dispersion. Freshwat Biol 16: 387-396.

Gandhi, HP (1961). Notes on the diatomaceae of Ahemdabad and its environs, Hydrobiology 17: 218-236.

Horn, H; Horn, W; Kohlsdorf, M (1987). Theoretical and pratical investigations on the heterogeneous distribution of plankton in the main basin of the Saindebach storage reservoir. Acta hydrochim Hydrobiol 15: 327-350.

Iwata, T; Nakano, S; Inoue, E (2003). Impacts of past riparian deforestation on stream communities in a tropical rain forest in Borneo. Ecol Appl 13: 461-473.

Jafari, N; Foroutan, A (2007). Integrating bioassessment as a tool for water resource management. International Journal on Algae 9(3): 274-293.

Jafari, N; Gunale, VR (2007). Seasonal dynamics of phytoplankton and their relationship with the environment in the Pavana and Mutha rivers. International Journal on Algae 9(1): 64-80.

Jafari, N; Gunale, VR; Trivedy, RK (2006). Biological assessment of an urban river using algal indices International Journal on Algae 8(1): 19-31.

Karr, JR (1981). Assessment of Biotic Integrity Using Fish Communities. Fisheries 6: 21-27.

Marzolf, RG (1990). Reservoirs as environments for zooplankton. In Thornton, K. W., L. B. Kimmel \& F. E Payne (eds), Reservoir Limnology: Ecological Perspectives. J. Wiley \& Sons, New York: 195-208.

Mathew, PM (1985). Seasonal trends in the fluctuations of plankton and physico-chemical factors in tropical lake and their interralationship. J Indian Fish Soc 17: 11-24.
Miltner, RJ; White, D; Yoder, C (2004). The biotic integrity of streams in urban and suburbanizing landscapes. Landscape and Urban Planning 69:87-100.

Prescott, GW (1951). Algae of the western great lakes area. Cranbrook Istitute of Science. Bulletin 31:p. 946.

Prescott, GW (1954). How to know fresh water algae. Won. C. Brown CO. Dubuque.

Stepenuck, KF; Crunkilton, RL; Wang, L (2002). Impacts of urban landuse on Macroinvertebrate communities in southeastern Wisconsin streams. J Am Wat Resour Assoc 38:1041-1051.

Threlkeld, S; Choinsk, E (1985). Plankton in a rapidly flushed impoudment: spatial distribution, population dynamics and community structure. Mem Ist ital Idrobiol 43: 105-118.

Trivedy, RK; Goel, PK (1986). Chemical and biological methods for water pollution studies, Karad India.

Van Den Brink, FWB; Van Katwijk, MM; Van Der Velde, G (1994). Impact of hydrology on phyto and zooplankton community composition in floodplain lakes along the Lower Rhine and Meuse. J Plankton Res 16: 351-373.

Wang, L; Lyons, J (2003). Fish and benthic macroinvertebrate assemblage as indicators of stream degradation in urbanizing watersheds. In: Simon TP (ed) Biological response signatures: Indicator patterns using aquatic communities. CRC Press, Boca Raton, FL. pp. 113-120

Hepp, LU; Milesi, SV; Biasi, C; Restello, RM (2010). Effects of agricultural and urban impacts on macroinvertebrates assemblages in streams (Rio Grande do Sul, Brazil). Zoologia 27: 106113. 